\title{
Inbred maize response to cover crops and fertilizer-nitrogen ${ }^{1,2}$
}

\author{
David Sotomayor-Ramírez ${ }^{3}$, Randy Huckaba ${ }^{4}$, Ricky Barnes ${ }^{4}$, \\ Ronald Dorcinvil ${ }^{5}$ and Jesús Espinosa ${ }^{6}$
}

J. Agric. Univ. P.R. 96(1-2):37-55 (2012)

\begin{abstract}
Maize (Zea mays L.) inbred seed production fields on the southern semiarid coast of Puerto Rico are usually fallow each year from May to September. Inbreds have lower seed yields than single-cross hybrids, yet producers tend to apply high fertilizer nitrogen (N) levels in efforts to increase yields. Inbred maize response to fertilizer-N was evaluated on the southern semiarid coast of Puerto Rico in a cover crop-maize cropping sequence in 2009, and in a fallow-maize sequence in $\mathbf{2 0 1 0}$ in a Fluventic Haplustoll. In general, maize produced after a legume cover crop of velvetbean (Mucuna prurience) or cowpea (Vigna unguiculata 'Iron Clay') had better yields and agronomic traits than maize after the fallow treatment. In 2009 , maximum seed yields of $2,726 \mathrm{~kg} / \mathrm{ha}$ were obtained with fertilizer- $\mathrm{N}$ application in the range of 112 to $224 \mathrm{~kg} \mathrm{~N} / \mathrm{ha}$. In 2010 , maximum seed yields of $1,447 \mathrm{~kg} / \mathrm{ha}$ were obtained with fertilizer- $\mathrm{N}$ application in the range of 84 to $211 \mathrm{~kg}$ Nha. Harvest index was 0.26 and 0.27 in 2009 and 2010 for all fertilizer-N treatments; higher than that for unfertilized maize. In general, agronomic traits were superior as a result of fertilizer-N application without consistent differences among fertilizer- $\mathrm{N}$ levels applied. The SPAD chlorophyll meter, leaf color index and leaf area index were suitable indicators of $\mathrm{N}$ status in the maize plants. Highest $\mathrm{N}$ use efficiencies were observed for the $112 \mathrm{~kg} \mathrm{~N} / \mathrm{ha}$ and $84 \mathrm{~kg}$ Nha fertilizer levels for 2009 and 2010, respectively, and decreased with increasing fertilizer- $\mathrm{N}$ applied. Fertilizer- $\mathrm{N}$ rates in soils, climatic systems, and maize inbreds similar to the ones tested should be between 84 and $112 \mathrm{~kg} \mathrm{~N} / \mathrm{ha}$. Greater amounts of fertilizer-N will result in decreased economic benefit and potential environmental contamination.
\end{abstract}

Key words: inbred maize, cover crops, fertilizer $\mathrm{N}$, crop response

${ }^{1}$ Manuscript submitted to Editorial Board 9 December 2011.

${ }^{2}$ We acknowledge cooperation from Dow-AgroSciences Staff, and UPRM-AES graduate and undergraduate students. Funding for this study was provided by Dow AgroSciences, LLC.

${ }^{3}$ Professor, Crops and Agroenvironmental Sciences, College of Agricultural Sciences, Univ. of Puerto Rico-Mayagüez Campus, PO Box 9030, Mayagüez, P. R. 00681; email: david.sotomayor@upr.edu.

${ }^{4}$ Dow AgroSciences, LLC Santa Isabel, Puerto Rico.

${ }^{5}$ Former graduate student, Univ. of Puerto Rico-Mayagüez; now at Department of Plant Sciences, North Dakota State University, PO Box 6050, Fargo, ND 58108, USA.

${ }^{6}$ Graduate student, College of Agricultural Sciences, Univ. of Puerto Rico-Mayagüez Campus. 
RESUMEN

\author{
Respuesta del maíz a cultivos de cobertura y fertilización con \\ nitrógeno
}

\begin{abstract}
La producción de líneas puras de maíz (Zea mays L.) se realiza principalmente en la zona semiárida del sur de Puerto Rico, donde los predios están en barbecho sin cobertura vegetal de mayo a septiembre de cada año. Las líneas puras tienen menores rendimientos que los híbridos, pero los productores tienden a aplicar altos niveles de fertilizante nitrogenado $(\mathrm{N})$ con la intención de aumentar los rendimientos. Se evaluó la respuesta de líneas puras de maíz a fertilizante- $\mathrm{N}$ en una secuencia de cobertura-maíz en 2009 y barbecho-maíz en 2010 en un Fluventic Haplustoll en la zona de los llanos costeros del sur de Puerto Rico. En general, el maíz producido luego de la cobertura de Mucuna prurience o Vigna unguiculata 'Iron Clay' mostró mayores rendimientos y mejores indicadores agronómicos que el maíz luego de barbecho. En el 2009, el rendimiento máximo en semilla de $2,726 \mathrm{~kg} / \mathrm{ha}$ se logró con la aplicación de fertilizante- $\mathrm{N}$ en el rango de 112 a $224 \mathrm{~kg} \mathrm{~N} / \mathrm{ha}$, y en el 2010 el rendimiento máximo en semilla de $1,447 \mathrm{~kg} /$ ha se logró con fertilizante- $\mathrm{N}$ en el rango de 84 a $211 \mathrm{~kg} \mathrm{~N} / \mathrm{ha}$. El índice de cosecha fue de 0.26 y 0.27 en 2009 y 2010 para los tratamientos fertilizados con $\mathrm{N}$, y fue mayor que en maíz sin fertilizar. El medidor de clorofila en hoja, el índice de color en hoja y el índice de área foliar fueron buenos indicadores de suficiencia de $\mathrm{N}$. La aplicación de fertilizante- $\mathrm{N}$ en suelos, clima y líneas puras de maíz similares a lo evaluado debe ser entre 84 y $112 \mathrm{~kg} \mathrm{~N} / \mathrm{ha}$. El uso de niveles de fertilización mayores resultará en un menor beneficio económico y mayor potencial de contaminación ambiental.
\end{abstract}

Palabras clave: Líneas puras de maíz, coberturas, fertilizante-N, respuesta a la fertilización

\title{
INTRODUCTION
}

Maize (Zea mays L.) is an important commodity crop that provides protein, oil, and starch for food, animal feed, ethanol, and other biobased products. The global area of maize production was estimated at $159.5 \times 10^{6}$ ha and $32.2 \times 10^{6}$ ha in the United States in 2009 (FAOSTAT, 2011). An annual grain yield increase of $125 \mathrm{~kg} / \mathrm{ha} / \mathrm{yr}$ in developed countries is attributed to the use of advanced agronomic management including fertilizers and improved genetics. Maize in Puerto Rico has traditionally been used for animal feed and to a lesser extent for fresh-market consumption, with local production accounting for only a small portion in terms of volume and economic value. The genetic materials that have been traditionally grown in Puerto Rico are open pollinated cultivars such as 'Diente de Caballo', and 'Mayorbela' (USDAARS, 1990), 'Mayorbela 05' (Beaver et al., 2006), 'Chulo' (USDA-ARS, 1996), sweet corn 'Suresweet' (USDA-ARS, undated), and commercial hybrids. Research has shown that with technological advances and adequate pest control, excellent commercial yields can be achieved for maize production in Puerto Rico (Sotomayor-Ríos, 1980; SotomayorRíos et al., 1984; Vicente-Chandler, 1993). 
During the past three decades, commercial winter nurseries and agro-biotechnology firms have been established in Puerto Rico, primarily on the southern semi-arid coast, in fields that were previously under sugarcane (Saccharum officinarum L.) production. Maize is grown for seed production, seed propagation, and hybrid selection in a production area estimated at 2,300 ha, distributed among seven major companies. Maize is grown primarily from November to March, in monoculture. When not under cultivation, the soils are kept weed-free by disking and other tillage operations. There is concern that current cropping practices may have a negative impact on soil quality and on agro-ecosystem sustainability. The use of cover crops has multiple benefits including reduced fertilizer inputs, less need for herbicides, improved seed yields as a result of enhancing soil health, less soil erosion, conserved soil moisture and improved water quality (Delgado et al., 2007; SAN, 2007). An evaluation of the agronomic performance of cover crops in this area has been reported elsewhere (Sotomayor-Ramírez et al., 2009), yet the effects of cover crops on maize production have not been reported.

Fertilizer-nitrogen $(\mathrm{N})$ continues to be the most frequent limiting factor in maize cropping systems, and considerable uncertainty exists regarding the optimum fertilizer- $\mathrm{N}$ application because of variations in soils, climatic factors, expected seed yields of genetic materials, and fertilizer recommendation philosophies (Vanotti and Bundy, 1994; Wilhelm et al., 1995; Fixen, 2006). At the local level, thirteen publications and various Master of Science theses have been published dealing with fertility/nutrient management aspects of maize. None of these publications have addressed fertilizer- $\mathrm{N}$ response or requirements of maize inbreds.

Inbred parental seed is the basic building block for the production of hybrids. Inbred lines typically are shorter, have less vigor, thinner stalks, smaller tassels, smaller ears, and lower seed yields compared to open-pollinated maize varieties or hybrids. A possible decreased rooting capacity makes inbreds more vulnerable to nutrient imbalances and deficiencies, drought stress, diseases and insects. In an effort to obtain higher seed yields, fields of inbred maize are frequently overfertilized. Beck (2002) suggested that best seed yields can be achieved with lower $\mathrm{N}$ rates (55 to $110 \mathrm{~kg} / \mathrm{ha}$ ) than that recommended by many companies and seed producers. Wilhelm et al. (1995) reported average optimum fertilizer- $\mathrm{N}$ rates of $86 \mathrm{~kg} \mathrm{~N} / \mathrm{ha}$ for various inbred maize lines.

In general, macronutrient levels $(\mathrm{P}, \mathrm{K}, \mathrm{Ca}, \mathrm{Mg}$ ) in soils of the southern semiarid coast of Puerto Rico are above soil test critical levels (Sotomayor-Ramírez and Martínez, 2006), which suggests that only maintenance application of most nutrients is warranted. However, 
site-specific information has not been gathered to prove that plant response to specific nutrients does not occur. Plant response to $\mathrm{N}$ fertilization is expected to occur because little $\mathrm{N}$ accumulates in the soil profile in inorganic form. The maize inbreds are planted after the rainy season, when most residual profile $\mathrm{N}$ leaching is expected to have occurred, and low soil organic matter levels impede accumulation of large $\mathrm{N}$ reserves in organic form. The overall objective of this paper is to provide information to improve fertilizer- $\mathrm{N}$ management in inbredmaize production systems in Puerto Rico. Specifically we wanted to: (i) determine maize seed yield response to fertilizer- $\mathrm{N}$ addition and cover crop management; (ii) evaluate some agronomic predictors of optimum nutrient status; (iii) evaluate potential $\mathrm{N}$ losses in the inbred maize production systems.

\section{MATERIALS AND METHODS}

The study site was the Mycogen Seeds Corp. ${ }^{7}$ research farm in Santa Isabel, Puerto Rico. The predominant soil series within the farm are Jacaguas (Loamy-skeletal, mixed, superactive, isohyperthermic Fluventic Haplustolls) and Fraternidad (Fine smectitic, isohyperthermic Typic Haplusterts) (USDA-SCS, 1979). Two field trials were performed. Trial 1 evaluated the effects of two cover crops and five fertilizer-N levels on maize seed yield response, and trial 2 evaluated the effect of five fertilizer-N levels on maize seed yield.

In trial 1, velvet bean (Mucuna prurience) and cowpea (Vigna unguiculata) 'Iron clay', were grown as cover crops during the summer of 2008. A fallow area adjacent to the cover crops was also included in the trial and was maintained by the application of glyphosate and shallow disking. At the end of the growing period, both cover crops were sprayed with glyphosate and incorporated via disking into the soil in late September 2008. Soil preparation prior to corn planting (during October and November 2008) included chisel plowing and disking.

Corn (inbred maize line $\mathrm{A}^{8}$ ) was sown 10 December 2008. Within each cover crop-fallow treatment, corn response to fertilizer-N application was evaluated, with four replications. The experimental design was a split-plot arrangement of a RCB with previous cover crop as the main plot and $\mathrm{N}$ level as the sub-plot. The sub-plots had an area of $42 \mathrm{~m}^{2}(4.6 \times 9.1 \mathrm{~m})$ with six rows (spaced $0.76 \mathrm{~cm}$ apart) per sub-plot.

\footnotetext{
${ }^{7}$ Company or trade names in this publication are used only to provide specific information. Mention of a company or trade name does not constitute a warranty of equipment or materials by the Agricultural Experiment Station of the University of Puerto Rico, nor is this mention a statement of preference over other equipment or materials.

${ }^{8}$ Inbred identification Lines have been omitted because of Dow AgroSciences policy.
} 
Final crop density for all treatments was on average 52,090 plants/ha. The fertilizer-N levels consisted of $0,112,150,186$, and $228 \mathrm{~kg} \mathrm{~N} / \mathrm{ha}$. All of the fertilizer-N treatments, except the control (N1) received 50 $\mathrm{kg} \mathrm{N} / \mathrm{ha}$ via sub-surface band at planting. A fertilizer-N surface band side-dressing of ammonium sulfate was applied 30 days after planting (DAP) (just prior to the six-leaf stage) to achieve final rates of 112, 150, $186,228 \mathrm{~kg} \mathrm{~N} / \mathrm{ha}$. At planting, all subplots received 67, 112, and $28 \mathrm{~kg}$ / ha of $\mathrm{P}_{2} \mathrm{O}_{5}, \mathrm{~K}_{2} \mathrm{O}$ and $\mathrm{ME}$ (minor elements), respectively. The sources of $\mathrm{P}, \mathrm{K}$, and $\mathrm{ME}$ were a fertilizer mix of triple superphosphate, muriate of potash, and Five-Star-Mix®, respectively, which was broadcast prior to planting. Irrigation was provided by drip irrigation following farm practices.

Agronomic data was gathered at 40, 54, and 70 (silking) DAP, and included plant height, leaf area index (LAI), and SPAD color index. SPAD-502 chlorophyll meter (Minolta Corp.) readings were taken from the youngest leaf with fully expanded collar at 40 and 54 DAP, and from the leaf opposite the top ear near silking. This leaf was also sampled for $\mathrm{N}$ sufficiency status. Plant greenness was assessed with an IRRI Leaf Color Chart (scale of 1 to 4 ) at 54 DAP. The LAI was taken with a LICOR-2000 (Li-Cor, Lincoln NE) (Li-Cor, 1992) from dawn until 8:00 AM (maximum) as specified by Malone et al. (2002). Plant nutrient (N, $\mathrm{P}, \mathrm{K}, \mathrm{Ca}, \mathrm{Mg}, \mathrm{S}$ ) concentrations were determined from indicator leaves at 70 DAP. At maturity (90 DAP), plant biomass (leaves, stems and husks) and nutrient content, and corn grain yield were determined.

In field trial 2, the field was under continuous corn cultivation (winter-early spring) followed by a fallow period (from late spring to fall) every year. The experimental design was a RCBD with five fertilizer $\mathrm{N}$ levels $(0,84,125,168,211 \mathrm{~kg} \mathrm{~N} / \mathrm{ha})$ and four replications. Each main plot was $19.8 \mathrm{~m}$ long and consisted of six rows with a $0.76 \mathrm{~cm}$ interrow spacing. A five-foot border separated the two main-plots, and two unfertilized maize rows separated the sub-plots. Corn (inbred maize line B) was sown 26 February 2010. Fertilizer-N was applied at 7 $\mathrm{DAP}$ at a rate of $28 \mathrm{~kg} \mathrm{~N} / \mathrm{ha}$ with half of the $\mathrm{N}$ applied as $\left(\mathrm{NH}_{4}\right)_{2} \mathrm{SO}_{4}$ $\mathrm{N}$ and the other half as $\mathrm{KNO}_{3}-\mathrm{N}$. One-third of the remaining amount of $\mathrm{N}$ for each treatment was applied at $28 \mathrm{DAP}(\mathrm{V} 4)$ in proportion 1:1 of $\left(\mathrm{NH}_{4}\right)_{2} \mathrm{SO}_{4}-\mathrm{N}$ and $\mathrm{KNO}_{3}-\mathrm{N}$. Two-thirds of the remaining amount of $\mathrm{N}$ was applied at $49 \mathrm{DAP}$ (VT) in proportions $2: 1$ of $\left(\mathrm{NH}_{4}\right)_{2} \mathrm{SO}_{4}-\mathrm{N}$ and $\mathrm{KNO}_{3}-\mathrm{N}$. All fertilizer-N was applied by fertigation. All plots received 67,112 , and $28 \mathrm{~kg} / \mathrm{ha}$ of $\mathrm{P}_{2} \mathrm{O}_{5}, \mathrm{~K}_{2} \mathrm{O}$ and $\mathrm{ME}$, respectively, in the same forms as in Trial 1.

Irrigation was provided by drip irrigation following farm practices. Agronomic data gathered included SPAD readings, plant height and leaf color as described in Trial 1. In Trial 2, SPAD-502 chlorophyll me- 
ter (Minolta Corp.) readings were taken at 33 DAP (V5) and 54 DAP (R1, near silking). Leaf plant nutrient sufficiency status was taken at 56 DAP (R1). Plant greenness was assessed as described previously at 33 DAP (V5, 31 March 2010) and 54 DAP (R1). Plant biomass (leaves, stems and husks) and nutrient content were determined at 77 DAP, and corn seed yields were determined at 91 DAP. For both trials, seed yields were expressed at $15.5 \%$ moisture, and nutrient efficiency indicators were quantified as described below.

Nutrient use efficiency was measured for a given genotype as the ability to produce a unit of seed yield per unit of nutrient applied (Baligar et al., 1990). There are two main ways to calculate nutrient use efficiency. One is based on the difference method, and the other on the balance method (Syers et al., 2008). Three indicators were calculated by using the difference method. The Agronomic Efficiency $\left(\mathrm{AE}_{\mathrm{Y}}-\mathrm{DM}\right)$ is defined as the increase in seed yield obtained per unit of nutrient applied. It can be calculated as:

$$
\mathrm{AE}_{\mathrm{Y}}-\mathrm{DM}=\left(\mathrm{YG}_{\mathrm{f}}-\mathrm{YG}_{\mathrm{u}}\right) / \mathrm{N}_{\mathrm{a}}
$$

where, $\mathrm{YG}_{\mathrm{f}}, \mathrm{YG}_{\mathrm{u}}$, and $\mathrm{N}_{\mathrm{a}}$ are seed yield in fertilized plants, seed yield in unfertilized plants, and nutrient applied, respectively.

The same index can be calculated by using the biological yield (BY) (seed + straw), and is defined as the increase in whole plant biomass per unit of nutrient applied $\left(\mathrm{AE}_{\mathrm{BY}}-\mathrm{DM}\right)$ :

$$
\mathrm{AE}_{\mathrm{BY}}-\mathrm{DM}=\left(\mathrm{BY}_{\mathrm{f}}-\mathrm{BY}_{\mathrm{u}}\right) / \mathrm{N}_{\mathrm{a}}
$$

The Apparent Recovery Efficiency (ARE-DM) is defined as the increase in whole plant nutrient uptake per unit of nutrient applied. It is also known as the apparent nutrient recovery (ANR) (Baligar et al., 1990) and is defined as:

$$
\mathrm{ARE}-\mathrm{DM}=\left(\mathrm{NBY}_{\mathrm{f}}-\mathrm{NBY}_{\mathrm{u}}\right) / \mathrm{N}_{\mathrm{a}}
$$

where NBY and $\mathrm{NBY}_{\mathrm{u}}$ are the whole plant biomass $\mathrm{N}$ in fertilized and unfertilized plants, respectively.

Three indicators were calculated by using the balance methods. The partial factor productivity (PFP-BM) (Syers et al., 2008) is defined as the amount of grain harvested per unit of $\mathrm{N}$ applied:

$$
\mathrm{PFP}-\mathrm{BM}=\mathrm{YG}_{\mathrm{r}} / \mathrm{N}_{\mathrm{a}}
$$

At the optimum value, it can be used for making fertilizer recommendations based on yield goal. 
The partial balance productivity (PBP-BM) (Syers et al., 2008) is defined as the amount of nutrient removed in grain $\left(\mathrm{NG}_{\mathrm{f}}\right)$ per unit of $\mathrm{N}$ applied. It can serve as an indicator of the proportion of $\mathrm{N}$ applied that is removed in the grain as:

$$
\text { PBP-BM }=\mathrm{NG}_{\mathrm{f}} / \mathrm{N}_{\mathrm{a}}
$$

It can be used for making fertilizer recommendations based on $\mathrm{N}$ removal.

The agronomic efficiency (AE-BM) based on the balance method is defined as the amount of nutrient removed in the whole crop per unit of $\mathrm{N}$ applied.

$$
\mathrm{AE}=\mathrm{NBY}_{\mathrm{f}} / \mathrm{N}_{\mathrm{a}}
$$

It can serve as an indicator of excess or deficit $\mathrm{N}$ in the system.

All leaf and vegetative biomass material was washed with tap water, dried and sent to a commercial laboratory (MDS Harris Laboratories()) for quantification of total $\mathrm{N}, \mathrm{P}, \mathrm{K}, \mathrm{Ca}, \mathrm{Mg}, \mathrm{S}, \mathrm{Fe}, \mathrm{Mn}, \mathrm{Zn}, \mathrm{Cu}$, and B. Soils were sampled for soil fertility parameters at 0 - to $15-\mathrm{cm}$ depth prior to corn planting. Results were similar for both trials; thus only the results for trial 1 are included (Table 1).

Statistical analyses were performed separately for the two trials. All data were subjected to analysis of variance by using Proc Mixed of SAS (SAS Institute, Cary, NC). The reported treatment means are the LSMeans output of the model when the main effects or interaction were significant. Contrasts were used to make comparisons between the control (no fertilizer- $\mathrm{N}$ applied) and the other fertilizer $\mathrm{N}$ levels. When appropriate, multiple comparisons among treatments were made with Fisher's Least Significant Difference test. When no significant difference among means for a particular variable was observed, the mean and standard error were presented. Correlation analysis was done by using the CORR procedure in SAS.

\section{RESULTS}

Trial 1. Fertilizer- $\mathrm{N}$ was the most important main effect influencing ( $\mathrm{P} \leq 0.05)$ maize agronomic traits, with cover crop affecting only four of these (Table 2). The fertilizer-N x cover crop interaction was significant only for leaf color index (54 DAP) and LAI (40 DAP), but these were not considered important due to the high fertilizer-N main effect significance and the trends observed for other parameters. Fertilizer $\mathrm{N}$ did not significantly affect the number of ears or grain $\mathrm{N}$ concentration with mean values of 67,099 ears/ha and $1.72 \% \mathrm{~N}$, respectively. 
TABLE 1.-General soil fertility parameters ${ }^{1}$ at the study site in trial 1 (2008-2009). Samples were taken after cover crop planting and before maize cropping.

\begin{tabular}{|c|c|c|c|c|c|c|c|c|c|c|c|c|}
\hline & $\mathrm{pH}$ & $\mathrm{OM}$ & $\mathrm{NO}_{3}-\mathrm{N}$ & Extractable P & $\mathrm{Ca}$ & $\mathrm{Mg}$ & $\mathrm{K}$ & CIC & $\mathrm{Fe}$ & $\mathrm{Mn}$ & $\mathrm{Zn}$ & $\mathrm{Cu}$ \\
\hline Cover crop & & $\%$ & $\ldots . . .$. & $\mathrm{mg} / \mathrm{kg}-\ldots$ & $\ldots$ & $--c$ & $/ \mathrm{kg}-$ & $\ldots$ & $\cdots$ & $\cdots-n$ & $\mathrm{~kg}-$ - & $\ldots$ \\
\hline Velvet bean & 7.6 & 2.51 & 18.4 & 21.8 & 24.5 & 6.2 & 0.60 & 31.6 & 6.4 & 1.5 & 2.1 & 6.6 \\
\hline Cowpea & 7.6 & 2.45 & 17.2 & 23.9 & 24.8 & 6.3 & 0.62 & 32.0 & 5.9 & 1.2 & 1.6 & 5.6 \\
\hline Fallow & 7.8 & 2.52 & 13.8 & 22.4 & 26.7 & 6.3 & 0.57 & 33.9 & 5.0 & 1.1 & 1.2 & 5.8 \\
\hline Mean & 7.7 & 2.49 & 16.5 & 22.7 & 25.3 & 6.3 & 0.60 & 32.5 & 5.8 & 1.3 & 1.6 & 6.0 \\
\hline Soil fertility level ${ }^{2}$ & $\mathrm{H}$ & M & $\mathrm{M}$ & $\mathrm{H}$ & $\mathrm{H}$ & $\mathrm{H}$ & $\mathrm{H}$ & $\mathrm{H}$ & $\mathrm{H}$ & $\mathrm{H}$ & $\mathrm{H}$ & $\mathrm{H}$ \\
\hline
\end{tabular}

${ }^{1} \mathrm{pH}$ was measured in 1:2 soil water ratio; $\mathrm{OM}$ is soil organic matter measured by weight loss on ignition; $\mathrm{NO}-\mathrm{N}$ is $1 \mathrm{M}$ KCl extractable; extractable $\mathrm{P}$ is that using the Olsen-P method; $\mathrm{Ca}, \mathrm{Mg}, \mathrm{K}$ were extracted by ammonium acetate and quantified by ICP; $\mathrm{CIC}$ is the cation exchange capacity; Fe, $\mathrm{Mn}, \mathrm{Zn}$ and $\mathrm{Cu}$ were extracted with DTPA-TEA.

${ }^{2} \mathrm{H}$ is high; $\mathrm{M}$ is medium; $\mathrm{L}$ is low fertility classification as described in Sotomayor-Ramírez and Martínez (2006). 
TABLE 2.-SUmmary of ANOVA to examine the effect of cover crop and fertilizer N levels, and contrasts between the control and fertilized plots, for various agronomic parameters of inbred maize during 2008-2009 (Trial 1).

\begin{tabular}{|c|c|c|c|c|c|c|c|c|}
\hline Effect & $\mathrm{CC}^{1}$ & $\begin{array}{c}\mathrm{N} \\
\text { Level }^{1}\end{array}$ & $\begin{array}{c}\mathrm{CC}^{*} \\
\mathrm{~N} \text { Level }\end{array}$ & $\begin{array}{l}\text { Contrast between } \\
\text { control and others } \\
\text { (significance level) }\end{array}$ & $\begin{array}{r}\text { Ferti } \\
\text { Mean }\end{array}$ & $\begin{array}{l}\text { izer } \mathrm{N} \\
\text { Standard } \\
\quad \text { error }\end{array}$ & Unfertili & $\begin{array}{l}\text { Standard } \\
\text { error }\end{array}$ \\
\hline $\begin{array}{l}\text { Seed yield }(\mathrm{kg} / \mathrm{ha} \\
\text { Stover wt }(\mathrm{kg} / \mathrm{ha})\end{array}$ & $\begin{array}{l}* * 2 \\
\mathrm{~ns}\end{array}$ & *** & $\begin{array}{l}\text { ns } \\
\text { ns }\end{array}$ & 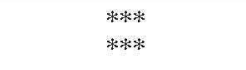 & $\begin{array}{l}2,726 \\
6,620\end{array}$ & $\begin{array}{r}87.3 \\
107.4\end{array}$ & $\begin{array}{l}1,788 \\
5,690\end{array}$ & $\begin{array}{l}177.5 \\
178.6\end{array}$ \\
\hline Ears/ha & $\mathrm{ns}$ & $\mathrm{ns}$ & ns & $\mathrm{ns}$ & & & & \\
\hline Harvest index & ** & *** & * & *氺水 & 0.26 & 0.01 & 0.21 & 0.01 \\
\hline Plant biomass (grain + stover) dry wt (kg/ha) & $\mathrm{ns}$ & 冰: & $\mathrm{ns}$ & *** & 9,346 & 151.2 & 7,474 & 294.1 \\
\hline Stover N (kg/ha) & $\mathrm{ns}$ & $* * *$ & ns & $* * *$ & 107.9 & 1.9 & 83.0 & 3.8 \\
\hline Grain $\mathrm{N}$ concentration $(\%)$ & $\mathrm{ns}$ & ns & $\mathrm{ns}$ & $\mathrm{ns}$ & & & & \\
\hline Grain N uptake (kg/ha) & $*$ & $* *$ & ns & $* * *$ & 39.7 & 1.5 & 25.7 & 3.0 \\
\hline Crop (stover + grain) N uptake (kg/ha) & $\mathrm{ns}$ & 冰: & ns & *冰水 & 149.3 & 2.8 & 110.4 & 5.8 \\
\hline SPAD chlorophyll reading (40 DAP) & $\mathrm{ns}$ & $* * * *$ & ns & $* * *$ & 50.6 & 0.4 & 43.1 & 0.7 \\
\hline SPAD chlorophyll reading (54 DAP) & $\mathrm{ns}$ & $* * * *$ & ns & $* * * *$ & 53.4 & 0.4 & 50.7 & 0.5 \\
\hline SPAD chlorophyll reading (70 DAP) & ** & $* *$ & ns & $* * * *$ & 54.3 & 0.2 & 52.6 & 0.5 \\
\hline Leaf color index (54 DAP) & $\mathrm{ns}$ & $* * *$ & $* *$ & $* * *$ & 4.2 & 0.1 & 3.3 & 0.1 \\
\hline $\mathrm{LAI}(40 \mathrm{DAP})$ & $\mathrm{ns}$ & $* * *$ & **** & $* * * *$ & 1.05 & 0.02 & 0.82 & 0.04 \\
\hline LAI (54 DAP) & $\mathrm{ns}$ & $* *$ & $\mathrm{~ns}$ & $* * * *$ & 1.71 & 0.03 & 1.47 & 0.05 \\
\hline LAI (70 DAP) & ns & $* *$ & $\mathrm{~ns}$ & $* * *$ & 1.64 & 0.03 & 1.40 & 0.06 \\
\hline Plant height (cm), (40 DAP) & $* * *$ & $* * *$ & ns & $* * *$ & 33.8 & 0.4 & 26.4 & 0.7 \\
\hline Plant height (cm), (54 DAP) & $\mathrm{ns}$ & $* * *$ & ns & **** & 59.5 & 0.8 & 48.0 & 1.1 \\
\hline Plant height $(\mathrm{cm}),(70 \mathrm{DAP})$ & ns & $* *$ & $\mathrm{~ns}$ & $* * * *$ & 64.2 & 1.1 & 59.9 & 1.3 \\
\hline
\end{tabular}

${ }^{1} \mathrm{CC}$ is cover crop; $\mathrm{N}$ level is fertilizer $\mathrm{N}$ treatment.

${ }^{2 *}, * *, * * * ;$ indicates significance at $\mathrm{P} \leq 0.1,0.05$, and 0.001 , respectively; ns denotes that no significant $\mathrm{P}>0.1$ main effect or interaction effects were detected. 
Maize seed yield was significantly affected by cover crop and fertilizer-N (Table 2). Maize yield ( $\mathrm{kg} / \mathrm{ha}$ ) was highest following velvet bean $(2,903)$ and cowpea $(2,522)$ and the latter was similar to that after fallow $(2,189)$. Harvest index followed the same trend as observed for grain yield, with highest values for maize grown after velvet bean $(0.27)$ and cowpea $(0.25)$ and the latter was similar to that after fallow (0.22). Maximum seed yield was obtained with $112 \mathrm{~kg} \mathrm{~N} / \mathrm{ha}$, with no significant difference among the higher fertilizer-N levels. Seed yield was $2,726 \mathrm{~kg} / \mathrm{ha}$ (mean of four fertilizer-N levels) with fertilizer $\mathrm{N}$, and $1,788 \mathrm{~kg} /$ ha without fertilizer $\mathrm{N}$.

Fertilizer-N rates of 112 to $224 \mathrm{~kg} / \mathrm{ha}$ did not result in significant differences in stover weight, harvest index, plant biomass, stover $\mathrm{N}$, grain $\mathrm{N}$ uptake, or crop $\mathrm{N}$ uptake, but these were higher than those of the control (Table 2). Fertilizer-N rates of 112 to $224 \mathrm{~kg} / \mathrm{h}$ a did not result in significant differences in indicator-leaf SPAD chlorophyll index at all stages of crop development, but these were higher than in the control (Figure 1). Indicator-leaf SPAD chlorophyll index increased
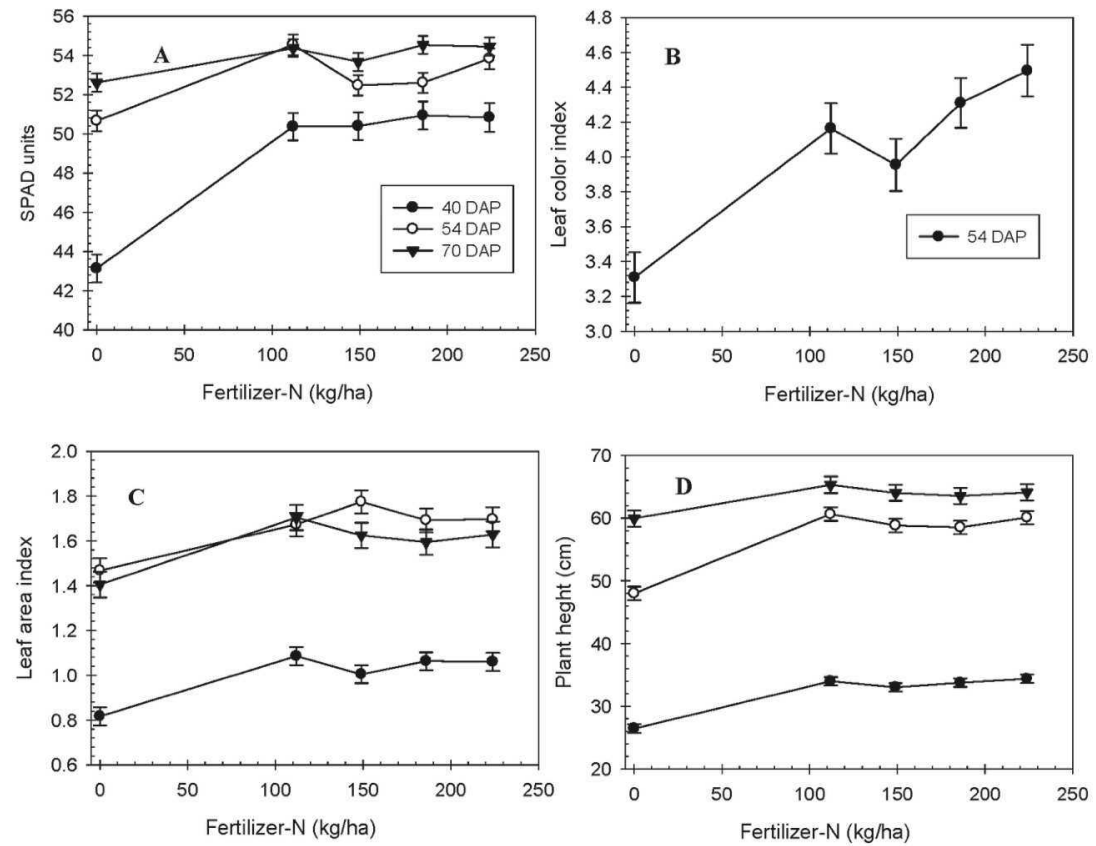

Figure 1. Scatter plots of the effect of fertilizer- $\mathrm{N}$ on $\mathrm{N}$ indicator parameters of inbred maize, (A) SPAD chlorophyll reading of indicator leaf, (B) Leaf color index, (C) leaf area index, (D) plant height, during 2008-2009 (Trial 1). 
with crop development stages from 40,54 and 70 DAP with mean values in fertilized plants of 50.6, 53.4, and 54.3, and mean values in unfertilized plants of $43.1,50.7$, and 52.6, respectively. Indicator-leaf color at 54 DAP was significantly higher in plants receiving fertilizer $\mathrm{N}$ than in the control. Plant height at all stages of crop development was significantly higher in treatments receiving fertilizer $\mathrm{N}$ than in the control. Plant height increased with crop development stages of 40,54 and 70 DAP with mean values $(\mathrm{cm})$ in fertilized plants of $33.8,59.5$, and 64.2 , respectively, and mean values in unfertilized plants of $26.4,48.0,59.9$, respectively.

Cover cropping improved indicator maize leaf nutrient concentration of $\mathrm{N}$ (3.32\% with cover crops, versus $3.17 \%$ without cover crops) and $\mathrm{S}(0.43 \%$ for cowpea and fallow versus 0.38 for velvet bean) (Table $3)$. The effect of fertilizer $\mathrm{N}$ was significant only for $\mathrm{Mg}(0.19$ in unfertilized maize and $0.17 \%$ in fertilized maize) and $\mathrm{Mn}$ concentrations. The interaction fertilizer $\mathrm{x}$ cover crop affected leaf $\mathrm{Fe}$ concentration. Contrary to what was expected, fertilizer- $\mathrm{N}$ treatments did not influence indicator leaf $\mathrm{N}$ concentration, with a mean value of $3.27 \%$.

Trial 2. Maize seed yield was significantly higher $(\mathrm{P} \leq 0.05)$ in fertilized treatments $(1,447 \mathrm{~kg} / \mathrm{ha})$ than in the control $(1,181 \mathrm{~kg} / \mathrm{ha})(\mathrm{Ta}-$ bles 4 and 5). No significant treatment effects were observed for stover dry-matter biomass, number of ears, harvest index, crop (grain + stover) biomass, stover $\mathrm{N}$ uptake, stover $\mathrm{P}$ uptake, stover $\mathrm{K}$ uptake, grain $\mathrm{N}$ concentration, crop (grain + stover) $\mathrm{N}$ uptake, crop (grain + stover) $\mathrm{P}$ uptake, crop (grain + stover) $\mathrm{K}$ uptake. Grain nutrient uptake was significantly higher $(\mathrm{P} \leq 0.05)$ in fertilized treatments as compared to the control, with mean values for the fertilized treatments for $\mathrm{N}, \mathrm{P}$, and $\mathrm{K}$

TABLE 3.-Nutrient concentrations of indicator leaf of inbred maize during 2008-2009 (Trial 1) and 2009-2010 (Trial 2).

\begin{tabular}{lrcccc}
\hline & \multicolumn{2}{c}{$2008-2009$ (Trial 1) } & & \multicolumn{2}{c}{$2009-2010$ (Trial 2) } \\
\cline { 2 - 3 } \cline { 5 - 6 } Variable & Mean & Standard deviation & & Mean & Standard deviation \\
\hline $\mathrm{N}(\%)$ & 3.27 & 0.15 & & -1 & \\
$\mathrm{P}(\%)$ & 0.36 & 0.02 & & 0.40 & 0.00 \\
$\mathrm{~K}(\%)$ & 2.04 & 0.09 & & 2.41 & 0.05 \\
$\mathrm{Ca}(\%)$ & 0.37 & 0.03 & & 0.60 & 0.01 \\
$\mathrm{Mg}(\%)^{2}$ & 0.17 & 0.03 & & 0.24 & 0.02 \\
$\mathrm{~S}(\%)$ & 0.42 & 0.04 & & 0.27 & 0.00 \\
$\mathrm{Fe}(\mathrm{mg} / \mathrm{kg})^{3}$ & 142.7 & 34.1 & & 62.3 & 2.2 \\
$\mathrm{Mn}(\mathrm{mg} / \mathrm{kg})^{2}$ & 103.7 & 29.2 & & 72.0 & 2.0 \\
$\mathrm{Zn}(\mathrm{mg} / \mathrm{kg})$ & 18.3 & 2.1 & & 16.4 & 0.6 \\
$\mathrm{Cu}(\mathrm{mg} / \mathrm{kg})$ & 14.2 & 1.7 & & -1 & \\
$\mathrm{~B}(\mathrm{mg} / \mathrm{kg})$ & 10.1 & 4.7 & & 29.4 & 1.4 \\
$\mathrm{Mo}(\mathrm{mg} / \mathrm{kg})$ & 1.9 & 1.0 & &
\end{tabular}

${ }^{1} \mathrm{~N}$ and $\mathrm{Cu}$ concentrations for Trial 2 are discussed in the text.

${ }^{2}$ Mean of fertilized treatments only for 2009.

${ }^{3} \mathrm{Fe}$ concentrations were affected by fertilizer x cover crop interaction for 2009 . 
TABLE 4. - Summary of ANOVA to examine the effect of fertilizer $N$ levels and of contrasts between the control and fertilized plots, for various agronomic parameters of inbred maize during 2009-2010.

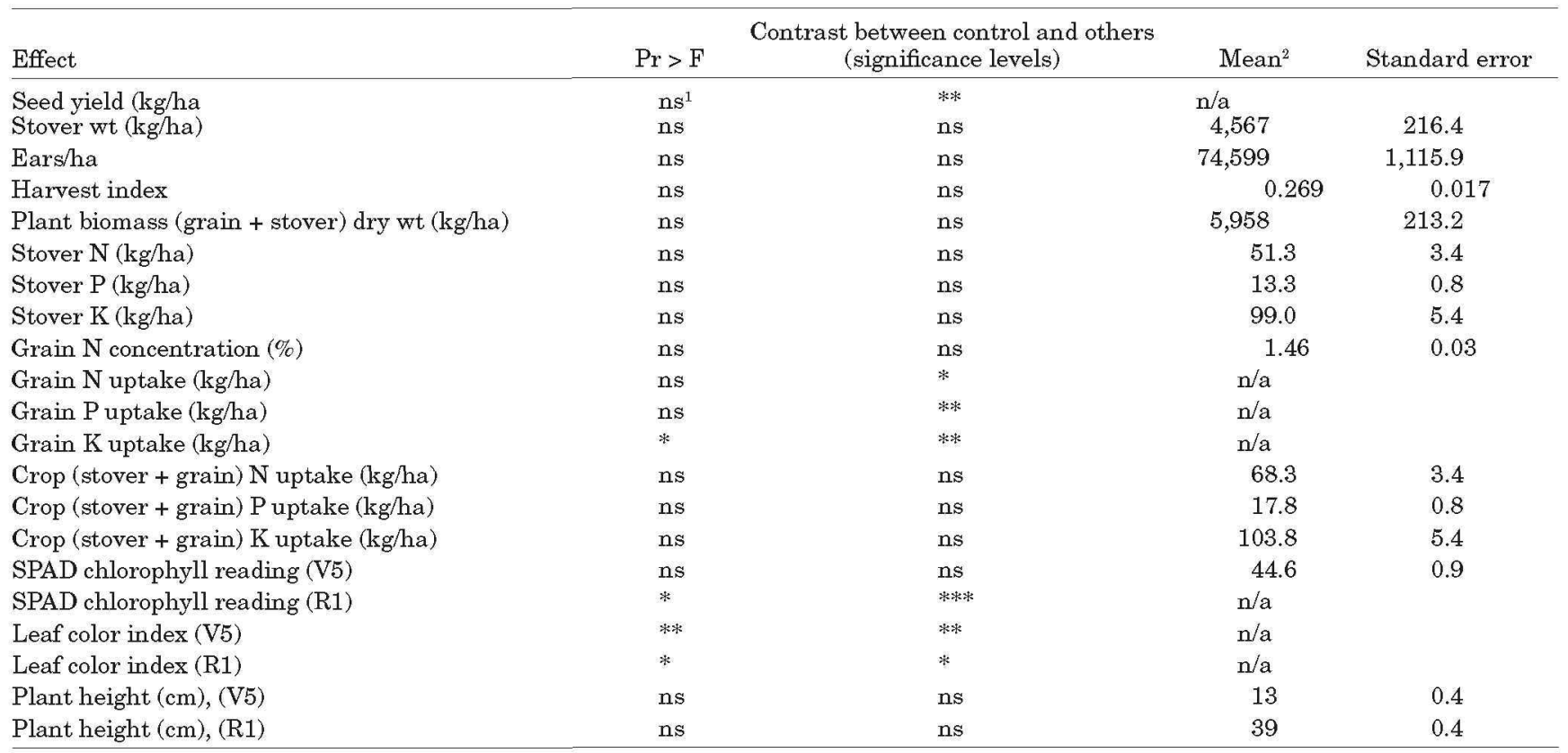

$1 *, * *, * * * ;$ indicates significance at $P \leq 0.1,0.05$, and 0.001 , respectively; ns denotes that no significant $(P>0.1)$ main effect or interaction effects were detected. ${ }^{2}$ The mean value represents that of all treatments when contrast effects were non-significant $(P>0.1)$. 
TABLE 5.-Treatment means of selected agronomic parameters of inbred maize during 2009-2010. Only parameters in which there was a significant fertilizer-N level effect are included.

\begin{tabular}{|c|c|c|c|c|}
\hline $\mathrm{N}$ level & Seed yield & Seed N uptake & Seed P uptake & Seed K uptake \\
\hline \multicolumn{5}{|c|}{ _ } \\
\hline $\begin{array}{l}0 \\
84\end{array}$ & $\begin{array}{l}1,181 \mathrm{~b}^{1} \\
1,449 \mathrm{ab}\end{array}$ & $\begin{array}{l}14.7 \mathrm{~b} \\
17.0 \mathrm{ab}\end{array}$ & $\begin{array}{l}3.8 \mathrm{~b} \\
4.9 \mathrm{a}\end{array}$ & $\begin{array}{l}3.9 \mathrm{~b} \\
5.2 \mathrm{a}\end{array}$ \\
\hline 125 & $1,308 \mathrm{ab}$ & $16.1 \mathrm{ab}$ & $4.5 \mathrm{ab}$ & $4.7 \mathrm{ab}$ \\
\hline 168 & $1,522 \mathrm{a}$ & $18.3 \mathrm{ab}$ & $5.1 \mathrm{a}$ & $5.3 \mathrm{a}$ \\
\hline \multirow[t]{3}{*}{211} & $1,495 \mathrm{a}$ & $19.3 \mathrm{a}$ & $4.5 \mathrm{ab}$ & $5.3 \mathrm{a}$ \\
\hline & $-\ldots+\ldots$ & Mean of fert & treatments & $-\ldots$ \\
\hline & $1,446.8$ & 17.6 & 4.7 & 5.1 \\
\hline
\end{tabular}

${ }^{1}$ Treatment means with different letters are significantly different as determined with Fisher's Least Significance Difference test $(\mathrm{P} \leq 0.05)$.

of $17.6,4.7$, and $5.1 \mathrm{~kg} / \mathrm{ha}$, respectively, and for unfertilized treatments for $\mathrm{N}, \mathrm{P}$, and $\mathrm{K}$ of $14.7,3.8$, and $3.9 \mathrm{~kg} / \mathrm{ha}$, respectively.

Although the SPAD chlorophyll reading taken from the indicator leaf at V5 growth-stage did not identify treatment differences, the same variable at $\mathrm{R} 1$ growth-stage adequately separated out the control (mean of 49.0) from the fertilized plots (mean of 51.2) (Table 6). The leaf color index taken at both V5 and R1 growth stages significantly identified treatment differences between the control and the fertilized plots. The mean value in the control was 3.05 and 3.34 at V5 and R1 in the control plots, and 3.41 and 3.56 in the fertilized plots, respectively.

TABLE 6.-Treatment means of selected $N$ indicator parameters of inbred maize during 2009-2010. Only parameters in which there was a significant fertilizer- $N$ level effect are included.

\begin{tabular}{|c|c|c|c|}
\hline N level & SPAD (R1) & Leaf color index (V5) & Leaf color index (R1) \\
\hline \multicolumn{4}{|l|}{$\mathrm{kg} / \mathrm{ha}$} \\
\hline 0 & $49.00 \mathrm{~b}^{1}$ & $3.05 \mathrm{c}$ & $3.34 \mathrm{~b}$ \\
\hline 84 & $51.05 \mathrm{a}$ & $3.16 \mathrm{bc}$ & $3.41 \mathrm{~b}$ \\
\hline 125 & $50.78 \mathrm{ab}$ & $3.22 \mathrm{bc}$ & $3.54 \mathrm{ab}$ \\
\hline 168 & $51.43 \mathrm{a}$ & $3.54 \mathrm{ab}$ & $3.72 \mathrm{a}$ \\
\hline 211 & $51.33 \mathrm{a}$ & $3.70 \mathrm{a}$ & $3.58 \mathrm{ab}$ \\
\hline \multicolumn{4}{|c|}{. } \\
\hline & 51.14 & 3.41 & 3.56 \\
\hline
\end{tabular}

${ }^{1}$ Treatment means with different letters are significantly different $(P \leq 0.05)$ as determined with Fisher's Least Significance Difference test. 
Leaf SPAD readings and Leaf Color Index values were slightly lower than those reported for Line A during 2009 at 54 DAP.

Leaf nutrient sufficiency levels were not affected by the treatments, except for $\mathrm{N}$ and $\mathrm{Cu}$, in which case the contrast between the control and the fertilized plots was possibly significant $(\mathrm{P}<0.1)$ for $\mathrm{N}$, and significantly different $(\mathrm{P}<0.05)$ for $\mathrm{Cu}$ (Table 3 ). Mean $\mathrm{N}$ concentrations in the control and fertilized plots were 2.14 and $2.32 \%$, respectively. Mean $\mathrm{Cu}$ concentrations in the control and fertilized plots were 17.8 and $16.6 \mathrm{mg} / \mathrm{kg}$, respectively.

Nitrogen use efficiency. In 2009, the effect of fertilizer $\mathrm{N}$ levels was observed for all nutrient use efficiency indicators. In general, $\mathrm{N}$ use efficiency decreased with increasing fertilizer-N applied. In 2010, fertilizer-N application did not have a significant effect on $\mathrm{AE}_{\mathrm{BY}}-\mathrm{DM}$ or ARE-DM, where mean values of 1.23 and 0.045 were obtained, respectively (Table 7). In 2010, the effect of fertilizer $\mathrm{N}$ application was observed for $\mathrm{AE}_{\mathrm{Y}}-\mathrm{DM}$, PFP-BM, PBP-BM, and AE-BM $(\mathrm{P}<0.05)$. The highest $\mathrm{N}$ use efficiency was observed for the $84 \mathrm{~kg}$ N/ha fertilizer level for all of the indicators. Nitrogen use efficiency decreased with increasing fertilizer-N applied.

TABLE 7.-Treatment means of selected $N$ use efficiency indicator parameters ${ }^{1}$ of inbred maize during 2008-2009 and 2009-2010. Only parameters in which there was a significant fertilizer- $N$ level effect are included.

\begin{tabular}{lcccccc}
\hline N level & $\mathrm{AE}_{\mathrm{Y}}-\mathrm{DM}$ & $\mathrm{AE}_{\mathrm{BY}} \mathrm{DM}$ & $\mathrm{ARE}-\mathrm{DM}$ & PFP-BM & PBP-BM & AE-BM \\
\hline $2008-2009$ & & & & & & \\
112 & $9.1 \mathrm{a}^{2}$ & $16.9 \mathrm{a}$ & $0.35 \mathrm{a}$ & $24.4 \mathrm{a}$ & $0.35 \mathrm{a}$ & $1.32 \mathrm{a}$ \\
149 & $6.2 \mathrm{ab}$ & $10.5 \mathrm{ab}$ & $0.21 \mathrm{~b}$ & $17.6 \mathrm{~b}$ & $0.26 \mathrm{~b}$ & $0.93 \mathrm{~b}$ \\
186 & $5.7 \mathrm{ab}$ & $9.3 \mathrm{~b}$ & $0.22 \mathrm{ab}$ & $14.9 \mathrm{bc}$ & $0.22 \mathrm{bc}$ & $0.81 \mathrm{c}$ \\
224 & $4.9 \mathrm{~b}$ & $8.4 \mathrm{~b}$ & $0.20 \mathrm{~b}$ & $12.6 \mathrm{c}$ & $0.18 \mathrm{c}$ & $0.69 \mathrm{c}$ \\
$2009-2010$ & & & & & & \\
84 & $3.4 \mathrm{a}$ & $\mathrm{ns}^{3}$ & $\mathrm{~ns}^{3}$ & $17.5 \mathrm{a}$ & $0.21 \mathrm{a}$ & $0.81 \mathrm{a}$ \\
125 & $0.7 \mathrm{~b}$ & & & $10.2 \mathrm{~b}$ & $0.13 \mathrm{~b}$ & $0.53 \mathrm{~b}$ \\
168 & $1.9 \mathrm{ab}$ & & & $9.0 \mathrm{bc}$ & $0.11 \mathrm{bc}$ & $0.44 \mathrm{~b}$ \\
211 & $1.5 \mathrm{ab}$ & & & $7.1 \mathrm{c}$ & $0.09 \mathrm{c}$ & $0.36 \mathrm{~b}$ \\
\hline
\end{tabular}

${ }^{1} \mathrm{AE}_{\mathrm{Y}}-\mathrm{DM}$ is the agronomic efficiency in yield by the difference method; $\mathrm{AE} \mathrm{BY}_{\mathrm{BY}}-\mathrm{DM}$ is the agronomic efficiency in seed and stover by the difference method; ARE-DM is the apparent recovery efficiency by the difference method; PFP-BM is the partial factor productivity by the balance method, PBP-BM is the partial balance productivity by the balance method, and AE-BM is the agronomic efficiency by the balance method.

${ }^{2}$ Treatment means with different letters are significantly different $(P \leq 0.05)$ as determined with Fisher's Least Significance Difference test.

${ }^{3} \mathrm{~ns}$, treatment effects were not significant $(\mathrm{P}>0.05)$. 


\section{DISCUSSION}

During 2008-2009 seed yield for Line A was double and for Line B about 26\% lower than reported acceptable yields for the same materials in the area. We estimate that the yield loss reduction in 2010 was due to the incidence of corn ear-worm (Helicoverpa zea) and, to a lesser extent to fall army-worm (Spodoptera frugiperda) damage. Therefore, 20 to 30\% higher grain yields could potentially be obtained than those reported here under similar soils and climatic conditions with improved pest control.

For 2009-2010, nutrient uptake values indicate that relatively low amounts of $\mathrm{P}$ and $\mathrm{K}$ were removed from the field during harvest. The crop (stover + grain) removed 18 and $104 \mathrm{~kg} / \mathrm{ha}$, of $\mathrm{P}$ and $\mathrm{K}$, respectively, of which about $26 \%$ of $\mathrm{P}$ and $5 \%$ of $\mathrm{K}$ is removed in the grain. Crop removal uptake data for $\mathrm{P}$ and $\mathrm{K}$ in 2008-2009 was unavailable. When no crop response to fertilizer nutrient application is expected, application rates should be in close balance with crop removal to ensure maximum efficiency and minimum environmental impact due to gaseous losses, leaching and runoff. The values determined in this experiment can serve as a general guideline for future $\mathrm{P}$ and $\mathrm{K}$ management. However, further work should examine crop response to fertilizer $\mathrm{P}$ and $\mathrm{K}$.

Seed yields in $2008-2009$ were significantly correlated $(\mathrm{P}<0.05)$ with certain yield components (stover biomass, harvest index, plant biomass, stover- $\mathrm{N}$, grain- $\mathrm{N}$ uptake, and crop $\mathrm{N}$ uptake), and with $\mathrm{N}$ use efficiency indicators in 2009 (Data not shown). Most of these are post-harvest and destructive. Therefore, the value of using them as diagnostic tools for $\mathrm{N}$ sufficiency may be in identifying these traits and selecting for those that are desirable in corn inbreds. Grain yields were significantly correlated $(\mathrm{P}<0.05)$ with crop agronomic indicators: SPAD chlorophyll meter, LAI, plant height, and leaf color. Since the SPAD chlorophyll meter readings and plant color are probably the easiest variables to measure, for Line A, leaf color index of 4.2 at $54 \mathrm{DAP}$ and SPAD chlorophyll meter readings of 50.6, 53.4 , and 54.3 can be used as $\mathrm{N}$ sufficiency indicators at 40,54 and 70 DAP. Similarly for Line B, leaf color index of 3.41 and 3.56 at V5 and $\mathrm{R} 1$, respectively, and SPAD chlorophyll meter readings of 44.6 and 51.2 at V5 and R1, respectively, can be used. Indicator leaf $\mathrm{N}$ concentration of $3.31 \%$ for Line A and of $2.14 \%$ for Line B could be used as sufficiency values. The applications of fertilizer $\mathrm{N}$ beyond the optimum response levels at the specified growth stage will not result in improved crop yields.

Fertilizer $\mathrm{N}$ improved the harvest index (partitioning between seed and total plant biomass) in 2009, but not in 2010. The harvest index in fertilized maize in 2009 and in 2010 was similar. An important con- 
tributor to the lower seed yields of inbreds may be the low harvest index characteristics.

Typical fertilizer- $\mathrm{N}$ recommendations for hybrid maize based on expected yield is $20 \mathrm{~kg} \mathrm{~N} / 1,000 \mathrm{~kg}$ grain, yet this approach does not account for soil $\mathrm{N}$ availability, $\mathrm{N}$ supply during the growing season, or other internal physiological factors influencing $\mathrm{N}$ uptake. On the basis of this rationale, with seed yields obtained in 2009 and 2010, fertilizer $\mathrm{N}$ recommendation would be 56 and $29 \mathrm{~kg}$ N/ha, respectively. Said fertilizer $\mathrm{N}$ levels would have been sufficient (i.e., between 41 and $65 \%$ in excess of that removed) to account for $\mathrm{N}$ export in grain with optimum yields (estimated at $39.7 \mathrm{~kg} / \mathrm{ha}$ in 2009 and $17.6 \mathrm{~kg} / \mathrm{ha}$ in 2010 ) and to maintain an adequate $\mathrm{N}$ balance in soil. With fertilizer- $\mathrm{N}$ recommendations of 56 and $29 \mathrm{~kg} \mathrm{~N} / \mathrm{ha}$, a substantial amount of the total $\mathrm{N}$ used by the crop (estimated at $149 \mathrm{~kg}$ N/ha in 2009 and $68 \mathrm{~kg} \mathrm{~N} / \mathrm{ha}$ for optimum yields) must come from the soil residual $\mathrm{NO}_{3}-\mathrm{N}$, and from soil $\mathrm{N}$ mineralization. Our empirical estimate of soil residual $\mathrm{NO}_{3}-\mathrm{N}$ and soil $\mathrm{N}$ mineralization (based on crop $\mathrm{N}$ extraction from unfertilized maize) was $110 \mathrm{~kg} \mathrm{~N} / \mathrm{ha}$ in 2009 and $64 \mathrm{~kg} \mathrm{~N} / \mathrm{ha}$ in 2010 . These values are an approximation as crop $\mathrm{N}$ uptake is influenced by climatic factors affecting the soil N mineralization process (Rice and Havlin, 1994) and crop genetic factors. Clearly, the optimum fertilizer-N levels of 112 and 84 $\mathrm{kg} \mathrm{N} / \mathrm{ha}$ found in these experiments were sufficient to account for the $\mathrm{N}$ removed in grain and to optimize yields, but it is not known if lower fertilizer-N levels may provide the same benefit. Under similar agronomic and climatic conditions and maize inbreds, it may be possible that the lowest fertilizer- $\mathrm{N}$ levels tested in these experiments could be sufficient to maintain yields and cropping system sustainability.

Potentially available $\mathrm{N}$ from previous velvet bean and cowpea cover crops was estimated at 101 and $144 \mathrm{~kg} \mathrm{~N} / \mathrm{ha}$, respectively (Sotomayor et al., 2009). However, crop $\mathrm{N}$ uptake was not influenced by cover crop or cover crop $\mathrm{x}$ fertilizer- $\mathrm{N}$ interaction. We presume that residual soil $\mathrm{N}$ from previous velvet bean or from cowpea was either inmobilized as organic matter in labile form or was lost from the system, and was therefore not directly and immediately available to the subsequent maize crop. Improved benefit of $\mathrm{N}$ availability from the cover crop will occur with the appropriate timing of the cover crop vegetative mineralization process with subsequent maize cropping.

Consideration of the fertilizer- $\mathrm{N}$ levels tested and the crop and grain removal values determined, residual soil $\mathrm{N}$ after maize cropping increased with fertilizer- $\mathrm{N}$ level applied, and was estimated at between -37 and $68 \mathrm{~kg} \mathrm{~N} / \mathrm{ha}$ in 2009, and between 14 and $136 \mathrm{~kg} \mathrm{~N} /$ ha in 2010. Stover N decomposition could add 108 and $52 \mathrm{~kg} \mathrm{~N} / \mathrm{ha}$ for 2009 and 2010, respectively. Thus the combination of residual soil $\mathrm{N}$ 
and stover $\mathrm{N}$ decomposition would add between 67 and $192 \mathrm{~kg} \mathrm{~N} / \mathrm{ha}$ (increased with fertilization level) to the soil and subsequent cropping. These values could be considered as those which could potentially be lost from the agroecosystem between cropping if soils are left fallow.

The highest nutrient efficiency indicators were obtained with 84 and $112 \mathrm{~kg} \mathrm{~N} / \mathrm{ha}$, for 2010 and 2009, respectively; these were not affected by cover crop or fertilizer-N x cover crop interaction. The indicators $\mathrm{AE}_{\mathrm{BY}}-\mathrm{DM}$ and ARE-DM were not affected by fertilizer-N in 2010. On average, 9.1 and $3.4 \mathrm{~kg}$ additional grain $\left(\mathrm{AE}_{\mathrm{BY}}-\mathrm{DM}\right)$ was produced per kilogram of fertilizer-N applied up to 112 and $84 \mathrm{~kg}$ N/ha in 2009 and 2010 , respectively. Under optimum conditions agronomic efficiencies of hybrid corn, as measured by $\mathrm{AE}_{\mathrm{BY}}-\mathrm{DM}$, are $30 \mathrm{~kg}$ grain $/ \mathrm{kg} \mathrm{N}$ applied. In this study, an optimum PFP-BM value of 24.4 in 2009 and 17.5 in 2010 was obtained. Recommended PFP values for hybrid corn are between 40 and 80 with a mean value of 50 in Nebraska (Doberman, 2008 as cited by Fixen, 2009). Nitrogen agronomic efficiency as expressed in terms of PFP values has been consistently improving in the United States with values of between 60 and 70 from 2000 to 2010 , so that higher yields can be achieved per unit of $\mathrm{N}$ applied. This progress is a result of improvements in fertilizer management, the use of diagnostic nutrient sufficiency indices, crop management practices and crop genetic improvement (Snyder, 2009). The inverse of our reported PFP values indicates that between 41 and $57 \mathrm{~kg} \mathrm{~N} / \mathrm{ha}$ are needed to produce $1,000 \mathrm{~kg}$ grain/ha. In inbred lines with characteristics similar to the ones evaluated, the PFP value can be used to guide fertilizer- $\mathrm{N}$ management, and is substantially different than for hybrid corn.

Maximum PBP-BM values of 0.35 and 0.21 indicate that between 29 and $48 \mathrm{~kg}$ fertilizer- $\mathrm{N}$ are needed for every $10 \mathrm{~kg} \mathrm{~N}$ removed in the grain in order to maintain an adequate $\mathrm{N}$ balance because of grain $\mathrm{N}$ removal from the field. Values $<1$ are indicative of excess $\mathrm{N}$, and optimum values should approach 1 . Crop managers can use the information to improve their field-by-field fertilizer $\mathrm{N}$ budgeting.

\section{CONCLUSIONS}

This paper reports on seed yield response of inbred maize to fertilizer $\mathrm{N}$ and cover crops, under specific crop management practices and specific fertilizer $\mathrm{N}$ sources, location, and timing. The results obtained may change because of variations in inbred lines used, and fertilizer and crop management patterns. The information can be used to quantitatively guide fertilizer-N management on the basis of each manager's philosophical approach. The specific options for making specific fertilizer $\mathrm{N}$ management decisions are beyond the scope of this work 
and will be addressed elsewhere. For example, a producer may decide to manage fertilizer $\mathrm{N}$ based on crop yield response only, or in combination with other aspects such as grain/fertilizer price ratios, pre-plant soil $\mathrm{NO}_{3}$ content, expected yields and efficiency estimates. The results of this study demonstrate that fertilizer $\mathrm{N}$ management of inbreds should be different from that for hybrid corn. Application of fertilizer$\mathrm{N}$ beyond crop response will not result in agronomic benefit.

\section{LITERATURE CITED}

Baligar, V. C., R. R. Duncan and N. K. Fageria, 1990. Soil-plant interaction on nutrient use efficiency in plants: An overview. In: V. C. Baligar and R. R. Duncan. Crops as enhancers of nutrient use. P. 351-373. Academic Press, San Diego.

Beaver. J., M. Salicetti and J. Sud, 2006. Release of maize [Zea mays L. (Walp)] open pollinated cultivar Mayorbela 05. J. Agric. Univ. P.R. 90:253-257.

Beck, D. L., 2002. Management of hybrid maize for seed production. CIMMYT. Available at: http://www.scribd.com/doc/7201555/Artcles-Maize-Seed-Prodn-CIMMYT

Delgado, J. A., M. A. Dillon, R. T. Sparks and S. Y. C. Essah, 2007. A decade of advances in cover crops: Cover crops with limited irrigation can increase yields, crop quality, and nutrient and water used efficiencies while protecting the environment. J. Soil Water Conserv. 62(5): 110A-117A.

Doberman, A., 2008. Nutrient use efficiency-measurement and management. In: Fertilizer Best Management Practices. International Fertilizer Industry Assoc. France.

FAOSTAT. 2011. FAO Statistics: http://faostat.fao.org/. Food and Agriculture Organization of the United Nations. Rome. Verified 10 September 2011.

Fixen, P. E., 2006. Use of yield goals for providing N rate suggestions: General concept. North Central Extension-Industry Soil Fertility Conference. 22: 57-66.

Fixen, P. E., 2009. Eficiencia de uso de nutrientes en el contexto de agricultura sostenible. Proceedings "Uso eficiente de nutrientes" XVIII Congreso Latinoamericano de la Ciencia del Suelo. J. Espinosa and F. García (editors). San José, Costa Rica. International Plant Nutrition Institute. P. 1-10.

LI-COR, 1992. LAI-2000 plant canopy analyzer operating manual. LI-COR, Lincoln NE.

Malone, S., D Ames-Herbert, Jr., and D. L. Holsouser. 2002. Evaluation of the LAI-2000 Plant canopy analyzer to estimate leaf area in manually defoliated soybean. Agron. J. 94: 1012-1019.

Mulvaney, R. L., S. A. Khan and T. R. Ellsworth, 2006. Need for a soil-based approach in managing nitrogen fertilizers for profitable corn production. Soil Sci. Soc. Am. J. $70: 172-182$.

Rice, C. W. and J. L. Havlin, 1994. Integrating mineralizable nitrogen indices into fertilizer nitrogen recommendations. In: J. L. Havlin and J. S. Jacobsen (ed.). Soil testing: Prospects for improving nutrient recommendations. SSSA Spec. Publ. 40. SSSA, Madison, WI. p. 1-13.

Snyder, S., 2009. Eficiencia de uso del nitrógeno: Desafíos mundiales, tendencias futuras. Proceedings "Uso eficiente de nutrientes" XVIII Congreso Latinoamericano de la Ciencia del Suelo. J. Espinosa and F. García (editors). San José, Costa Rica. International Plant Nutrition Institute. P. 11-19.

Sotomayor-Ramírez, D. and G. A. Martínez, 2006. The status of phosphorus and other fertility parameters in soils of Puerto Rico. J. Agric. Univ. P.R. 90: 145-157. 
Sotomayor-Ramírez, R. Barnes and R. Huckaby, 2009. Graduate Student Cooperation Agreement Summary Report \#2. April 2009.

Sotomayor-Ríos, A., 1980. Performance of twelve corn hybrids and selections in three consecutive crops on same site and year. J. Agric. Univ. P.R. 64:170-179.

Sotomayor-Ríos, A., A. Quiles-Belén and S. Torres-Cardona, 1984. The potential for corn production in Puerto Rico (Spanish). Revista Colegio de Agrónomos de Puerto Rico. $3 \mathrm{pp}$.

Sustainable Agriculture Network (SAN), 2007. Managing cover crops profitably. A. Clark (editor). Cooperative State Research Education, and Extension Service, USDA, Univ of Maryland, Univ. of Vermont. Sustainable Agriculture Network, Beltsville, $\mathrm{MD}$.

Syers, J. K., A. E. Johnston and D. Curtin, 2008. Efficiency of soil and fertilizer phosphorus use. Reconciling changing concepts of soil phosphorus behavior with agronomic information. FAO Fertilizer and Plant Nutrition Bulletin 18. Food and Agriculture Organization of the United Nations. Rome, 2008.

USDA-ARS, 1990. The release of four maize germplasm populations. United States Department of Agriculture, Washington, D.C.

USDA-ARS, 1996. The release of flint corn cultivar 'Chulo'. United States Department of Agriculture, Washington, D.C.

USDA-ARS, undated. Release of sweet corn variety Suresweet. United States Department of Agriculture, Washington, D.C.

USDA-SCS (Soil Conservation Service), 1979. Soil survey of Ponce area of southern Puerto Rico. United States Departement of Agriculture, Soil Conservation Service.

Vanotti, M. B and L. G. Bundy, 1994. Corn nitrogen recommendations based on yield response data. J. Prod. Agric. 7: 249-256.

Vicente-Chandler, J., 1993. Una agricultura para los "90". Special Report to the Secretary of Agriculture. Department of Agriculture of Puerto Rico. pp. 185.

Wilhelm, W. W., B. E. Johnson, R. Koopman and W. R. Peterson, 1995. Yield and N uptake of inbred corn with reduced $\mathrm{N}$-fertilizer application. Clean Water-Clean Environment $-21^{\text {st }}$ Century: Team Agriculture Working to Protect Water Resources. Conference Proceedings, Vol. 2L Nutrients. March 5-8, 1995. Kansas City Missouri. American Society of Agricultural Engineers. Pp. 243-246. 
